\title{
AN ASSESSMENT OF AUTONOMY AND FREEDOM IN NIGERIAN UNIVERSITIES
}

https://doi.org/10.47743/jopafl-2021-22-08

\author{
Timothy Igbakula UTILE \\ Department of Political Science, Benue State University, \\ Makurdi-Nigeria \\ timutile1@gmail.com
}

\begin{abstract}
This is an assessment of Autonomy and Freedom in managing Nigerian Universities. The study was based on organization theory, which emphasizes that every organization has some level of autonomy and freedom to handle its affairs. The primary data collected through the use of the questionnaire method and standard interview method were analyzed using frequencies and chi-square. The research found that proponents of autonomy are of the view that the call for the government to relinquish autonomy to universities recognize that the right to autonomy is not absolute, but rather conditional on the government's obligation for greater university funding in particular and for determining the goals and broad outlines of higher education in Nigeria in general. The study also discovered that university autonomy craves the indulgence of government to reposition its university agencies to better fulfil their responsibilities by way of assisting to provide adequate funding, well-articulated policies, plans and machinery that would ensure the attainment of university goals and objectives with minimal interference. However, the government must revisit the same law to fully capture financial autonomy, allowing universities to generate funds through a reasonable costsharing approach while the government maintains its legitimate role of adequately funding universities to train and retain quality manpower for the country's overall economic and social development.
\end{abstract}

Keywords: Funding, Management, University Autonomy

\section{Introduction}

Education is viewed as a "par excellence" tool for achieving national development in Nigeria. It has seen active participation by non-governmental agencies, communities, and individuals, as well as government intervention to some level. However, with Nigeria's population growing to over 200 million people, according to the 2019 estimated figure, the need for all levels of education has increased, as has the necessity to train individuals to gain excellent education for national development. In its broad aims, Nigeria's national policy document on education highlights the importance of Nigerians living in unity and harmony as one indivisible, indissoluble, democratic, and sovereign nation founded on the ideals of freedom, equality, and justice. As a result, the country's educational philosophy emphasizes the need to: develop the individual into a sound and effective citizen; integrate the individual into the community; and provide equal access to educational opportunities for all citizens of the country, both inside and outside the formal school system. Based on the aforementioned idea, Nigerian universities as citadels of learning strive to develop the Nigerian man into a full being capable of adjusting to his surroundings in order to promote and enhance development. To achieve capacity building, succeeding Nigerian administrations must ensure that university education specifically trains and retains manpower capable of advancing science and technology, which is the bedrock of a productive economic system that underpins so much of what is achievable in Nigeria. University education is essential for bringing about desired change in any country; in this 
light, the necessity for university education increased when Nigeria gained independence in 1960. As a result, universities were founded to serve the three regions (the Northern, Southern, and Eastern Regions); these first-generation universities were charged with training the necessary manpower to fill the void left by the departure of colonial expatriate staff. Each of the established universities had well-defined operational boundaries and autonomy (Ojo, 1990).

The system has indeed witnessed phenomenal growth both in the number of universities and student enrolment. Total student enrolment on the other hand rose from 627,609 in 2002 to 1,711,134 in 2017 (Varrella, 2020). Available statistics from The Joint Admissions and Matriculation Board (JAMB), and the National Universities Commision (NUC) indicate that over millions of candidates apply for admissions into Nigerian universities every year, and out of these about 30\% get admitted. The majority of candidates are denied admission because existing universities lack the necessary facilities to accommodate them. This suggests that something is fundamentally wrong, because a total of 170 universities (43 federally controlled, 48 state-owned, and 79 privately owned) can only accommodate less than two million students, indicating that much work needs to be done to expand their carrying capacity. This becomes a problem for university autonomy and university funding in Nigeria. Universities were established with autonomy. However, in recent times, though the Laws establishing these universities are still intact with some reviewed, universities are no longer allowed the flexibility of the powers that be to manage their affairs in consonance with the Laws establishing them, hence the erosion of their autonomy. The concept of university autonomy is very essential in the management of universities all around the world. Several academics have characterized it in various ways. It is defined by Ojo (1990) as "the legal freedom afforded to each university to conduct its own affairs and policies without undue interference from outside bodies, persons, or, most importantly, from the government that chooses to support it in most parts of Africa." University autonomy, according to Ibidapo-Obe (2005), is "a system in which individual universities handle their own affairs without undue interference from other entities, particularly the government and private proprietors." This clarifies the subject by stating that the effective management of the university system is dependent on the provisions of the law governing the establishment of each university.

The autonomy principle guided the running of these universities, which provided them the power to select their academic curricula with some measure of regulatory oversight (Ojo, 1990). The lack of a university in Nigeria until the Colonial Administration created the University College of Ibadan in 1948 was partly responsible for the near monopoly of university administration and top civil service positions in Nigeria by expatriate officers before independence. However, in recent years, university autonomy has been eroded. The University Senate's autonomy would be severely eroded as a result of this. The Academic Staff Union of Universities (ASUU) has recently pushed for university autonomy, claiming that Nigerian universities require autonomy to strengthen and control their internal management mechanisms, particularly when it comes to the appointment of Vice-Chancellors and other senior officers. ASUU (2002), in reiterating its autonomy argument, stated that the only way for Nigeria to compete in the growing global community is to provide high-quality education to its population, an education capable of changing a large number of people. ASUU stressed that no country on the planet has ever been able to 'beg' its way to development. For example, Japan, one of the world's wealthiest 
countries, does not have any mineral deposits but has grown as a result of its attention to education, particularly technical education.

One strategy to encourage university-level education is to implement a deliberate policy that promotes autonomy. Such autonomous reforms should aim to restore sanity, raise academic standards, and put the entire university system into right perspective, allowing it to compete favourably with international university norms. For our universities, the reform should also attempt to strengthen and increase institutional autonomy, more system differentiation, governance, and quality assurance systems (Saint, Hartnett \& Strassner, 2003). The restoration of autonomy to university management should seek to ensure that higher education as a whole reinforces its role as a powerful force that promotes the nation's growth and development, as well as create a more conducive atmosphere for university internal administration and management. The autonomy reform pushed by this research work is that which scholars like Sorkaa (2001), Sambo (2002), Salim (2003), and Obaji (2005), believe can create a more flexible and responsive system of university teaching and research that, over time, will contribute increasingly to national innovation capacities, productivity gains and economic growth (Sainta, et al., 2003). Even though government on the contrary intends that financial autonomy (generation of funds) should be a cardinal focus of its reform, an issue ASUU disagrees on; it is clear that university autonomy is fundamental to the restructuring of or reformation of the universities, which both government and all the unions agree is fundamental and necessary now.

The continuous, persistent and stringent erosion of University autonomy and the infraction of laws governing the operation of government-owned universities by its stakeholders is an age-long problem bedevilling the effective management of governmentowned universities in Africa in general and Nigeria in particular. History has it that universities in Africa were established with strong bureaucratic structures and firm controls to ensure loyalty and adherence to the norms of the colonial authorities (Altbach, 2002). To date, government-owned universities in Nigeria suffer a lot of setback in terms of falling standards, deteriorating infrastructure, and poor human resource development, which emanates from years of poor funding and direct interference into its day to day administration by government agencies and some regulatory bodies responsible for standards, quality, and admissions. Poor funding has been blamed for being responsible for the falling standards and poor human resource development. As a result, it is quite challenging for Nigerian universities to recruit, sustain, and retain some of their talents. As such, quality human resource is lost to the organized private sector or to some foreign universities that provide better options than what is obtained in Nigeria.

In spite of the foregoing, the erosion of university autonomy is still on the increase as Government still interferes in appointment of key managers of the system such as Chancellors, Pro-Chancellors and external members of the governing councils to run the affairs of universities without recourse to the system. Such appointments are made most times to reward political patronage indeed, it has become common place to have on some university councils members whose knowledge of University affairs is ill equipped. This research will carefully examine the issue of autonomy and see how best it can help in improving the management of the university system in Nigeria and the extent to which it can better the lot of the Nigerian educational system. 
The rest of this paper is organized as follows: section two presents a review of related literature while section three presents Methodology. Section four covers empirical results and discussion while section five offers conclusion and policy recommendations.

\section{Review of related literature}

\section{Conceptual Clarification}

University Autonomy: University autonomy implies: the freedom of universities to select their students and staff by criteria chosen by the universities themselves; autonomy to shape their curriculum and syllabus; and the freedom to decide how to allocate among their various activities, such funds as are made available to them. This clarification demonstrates that the university as an institution does not claim autonomy in all fields, but just in certain. Legislative authority or executive suasion tied to financial power are common examples of government influence. Executive influences can be exerted by government through appointment of vice-chancellors, members of the governing councils and on matters of salaries and conditions of service/funding. However, university autonomy can only be meaningful in terms of a university carrying out its functions of research and teaching where it is allowed to govern itself, secure from the day to interference of the state and the interplay of politics.

University Management: University management is an art of management which in its widest application include the whole art of carrying into effect any policy, plan or undertaking. The term as used in this study is confined to that class of officers that engage in the day-to-day administrative management of the affairs of the university. These include the Vice-Chancellor, his deputy, the Provost and his deputy, the Registrar, the Bursar, the University Librarian, the administrative staff, the Deans of faculties and students, the various heads of department, sub-deans and all those engaged in one form of administration or the other in the university.

\section{Balancing Government Control with University Autonomy}

Section 6(3) of the 1991 ACT establishing the Benue State University Makurdi, for example has specified the functions of Senate which reflect institutional autonomy. Under these functions the senate of the university has:

- $\quad$ the freedom to select its students and staff by criteria chosen by the university;

- $\quad$ the freedom to shape its curriculum and syllabus;

- $\quad$ the freedom to decide how to allocate among its various activities, funds that are made available to it on approval by council;

- $\quad$ the freedom to establish colleges and faculties from time to time on the approval of the council, among others.

Autonomy as outlined in the Benue State University ACT shows that universities do not claim autonomy in every sense, but only in certain sensitive areas where university ideals are essential and have to be maintained. Any erosion of such ideals by political considerations or extraneous forces might lead to the lowering of standards (Ojo, 1990). University autonomy is therefore not the right of the individual professional but the right of the institution to govern itself. 
Nevertheless, the principle of complete non - interference in university affairs cannot be sustained since such freedom does not exist without some limitations anywhere in the world. This implies that government or proprietors of universities do exert reasonable level of control over universities to account for the resources allocated to it, 'for he who pays the piper needs to dictate the tune'. Autonomy, therefore, could be described as a double-edged sword that requires the government's proper funding of universities, while government, on the other hand, expects universities to maintain quality in what they do. The role of government regulatory agencies therefore cannot be completely seen as unnecessary interference in the affairs of universities but should be seen as a legitimate duty on the side of government. On the contrary, universities should have the opportunity to oppose any attempt by government to erode their internal administration or impinge on their traditional autonomy as reflected in the laws establishing them.

It has been emphasised in this work that even in Europe, university education has not enjoyed complete autonomy in state-supported institutions. However, universities that started as faith-based and privately owned in Europe and America such as Oxford and Harvard, over time overcame their proprietor's control through endowments, tuition fees and private sector counterpart funding they enjoyed and are now fully autonomous. These universities, however, have continued to intensify research in areas that have brought about the rapid development of their respective economies.

In Nigeria however, private sector support for university funding is still very poor. This largely is responsible for the over-dependence on government subvention by universities, hence the escape route becomes impossible.

\section{An Assessment of Autonomy in Nigeria Universities}

As noted earlier, education is described as a powerful force in the growth, development or change of a nation. Development enhances economic growth, political stability and the distribution of investment capital. Thus, the wealth of a nation to a large extent covers the distribution of other necessities of life such as leisure, pleasure, information, decision-making, rights, responsibilities and education (National Association of University Women, 1998). The role of education in development is, therefore, that of imparting skills and knowledge to people as an instrument of development in all facets of life. The attainment of good education for development by any government requires good governance. Studies have it that before the 1999 decision of the Federal government to grant autonomy to universities for the enhancement of good education, there have been numerous moves, seminars and conferences, over the years on the subject of autonomy. However, the major indices deliberated upon included funding, admission of students, composition of governing councils and the appointment of Vice-Chancellors and other principal officers (Obasanjo, 2000).

Outside the university system, it is often believed that Nigerian universities have been granted more than their fair share of autonomy. In fact, it is also believed that the same autonomy has become a monster that has of recent been trying to destroy the system it was created to strengthen (Sambo, 2002). Sambo further reiterates that, people who hold this negative view cite as a case of autonomy gone haywire, the profusion of graduates in certain areas "irrelevant" to our circumstances as a third world nation and thereby creating unemployment problems to the economy. It should be noted, however, that no discipline 
is useless; government should use the available resources and expand its economic base and capacity so that adequate employment can be provided for graduates of all fields.

The proponents of autonomy, on the other hand, have always insisted that Nigerian universities do not have any reasonable autonomy. They argue that the universities are tied to the financial apron strings of their provider of finances - that is government. So they continue, the universities are forced to dance to the tunes composed and rendered outside their portals. Indeed, it can be said that university autonomy is an unwritten covenant between society and the academic community which concedes to the latter a free will to determine its guiding principles and self-regulate itself. The perception of universities as ivory towers in which egg-heads were separated from the rest of society for the serious application of their minds to the pursuit of the truth, found expression in the concept of university autonomy is also no longer tenable. This age-old tradition has grown to be universally accepted and the best examples of university autonomy can be found in the United States of America and Europe. The decision of the Federal Government to grant autonomy to universities in line with the above-mentioned advantages is a move in the right direction. It is the duty of all involved in the management of universities to join hands with the government to ensure the smooth take-off and implementation of the autonomy.

\section{Governance Structure of Government and Private owned Universities}

The governance structure is well set out in the University Laws. At the apex of the governance structure, in public universities, is the Visitor (Mr. President) in case of Federal Universities and the governors in the case of state universities. The Visitor appoints the Chancellor, Chairman, Governing Council as well as the external members of the Governing Council. Other bodies provided for in the law are; the Senate with the ViceChancellor as Chairman; congregation; and Convocation. Memberships of these bodies are outlined in the law. Their functions and powers are also clearly stated. The Council enacts statutes and the Senate makes regulations. Private Universities have a slightly different structure. At the apex of the governance structure is the proprietor; usually a foundation specifically put in place for the purpose of establishing the university. The promoter of the university, who may not be a member of the registered trustees, may be the chief financier. For faith-based universities, the religious leader may serve in this capacity. One significant difference in the structure is the introduction of a buffer body, (the board of trustees) which is appointed by the proprietor. The board of trustees has the responsibility of appointing the Chairman and external members of the Governing Council.

\section{Legal Perspective of University Autonomy}

The functions of the university are usually clearly stated in its laws, which confer on the university such powers, as in its opinion are necessary to effectively advance the objects of the university. These functions usually include the following:

(i) to provide courses of instruction and learning in the identified disciplines;

(ii) to make provisions for research and for the advancement of knowledge in the branches of learning in the identified disciplines for such persons and in such manner as it shall determine; 
(iii) to institute the various cadres in the career profile for academic and non-academic staff;

(iv) to award degrees, in the identified disciplines, including honorary degrees, diplomas, certificates and other academic distinctions such as fellowships bursaries, prizes, titles etc;

(v) to acquire by purchase or gift movable or immovable property and to sell, lease, mortgage or otherwise alienate or dispose of any such property;

(vi) to establish campuses, facilities, schools, extra-moral departments and other teaching and research units within the university from time to time;

(vii) to provide the necessary physical and infrastructural facilities including libraries, sporting facilities, lecture halls and others necessary for discharging the responsibilities implicit in its objects;

(viii) subject to the provisions of the law, to invest any monies appearing to the university and such other monies that may not be immediately required for recurrent expenditure;

(ix) to borrow money;

(x) to demand and receive from students such fees as the University may determine subject to the directives of the Minister for Education in case of Federal owned Universities and the appropriate offices in the case of State owned and Private Universities;

(xi) to provide for the welfare and discipline of the students and other members of the

University Community.

Consequently, the law gives enough leverage to the system for effective institutional management. The problem, therefore, is not the lack of provisions, with implications for institutional autonomy, but rather government decrees (in the case of military government), laws, acts and circular letters and any relevant prescriptions in the constitution (Okojie, 2005). The Decree No.1 of 1974 and Decree No. 49 of 1988 now both Acts, amending Decree (Act) No. 16 of 1985, Decree (Act) No. 9 of 1993, Decree (Act) No. 11 of 1993, Decree (Act) No. 25 of 1996, and many government decrees (acts), circulars and statutes of councils of universities need to be reviewed as a result of the existing conflicts and confusion. They all undermine the degree of university autonomy. Too much government interference does not guarantee the level of autonomy and academic freedom required in the Ivory Tower. University autonomy may be classified as follows: academic autonomy; administrative autonomy; financial autonomy; and institutional autonomy.

Academic Autonomy/Academic Freedom: The responsibility of Council is to oversee the financial and administrative management of the system. The Senate handles all academic issues including students' discipline. However, no specific and explicit legal provisions have been made to ensure academic freedom. It is yet to be seen if the university autonomy bill speculated will be made available to cater adequately for academic freedom. For now there is no evidence of sanctions or repressive actions from government in respect of extreme criticism or pronouncements. The Senate, to a large extent, through its committees is responsible for whom it admits, decides when to teach, whom to teach and how to teach the prescribed courses. It has sole responsibilities for assessing students for the award of degrees. The university, laws also indicate that Senate can create new programmes, make recommendations for the establishment of new faculties, departments and academic units. 
Consequently, the system exercises its academic autonomy through its senates and its committees.

Administration Autonomy: The management of a university's system becomes more complex as it grows. The first of the problems it faces is institutional governance. The Nigerian public universities, and to a large extent private universities, have adopted the European model. The council, a collegial body elected by the visitor, congregation, senate and convocation, is the highest authority within the university. In the private universities, the proprietor appoints the external members of councils. However, the general administration is under the control of the Vice-Chancellor. The process for the appointment of the Vice-Chancellor is prescribed by Act (No.11) of 1993. It is an internal mechanism for the first stage with little interference from outside. This internal mechanism involves some democratic process and interviews by a joint senate-council committee. However, the requirement is for a list of three (3) short listed candidates to be sent to the visitor in the case of public universities. This does not make for administrative autonomy. It is hoped that university autonomy will confer the absolute responsibility on the university governing council (Adamolekun, 2000). The central administration in the university determines the established positions with inputs from the faculties/departments and units. Authority in the university is diffused and unlike in a corporate setting, each segment has its defined responsibilities. True administrative autonomy will feature in the university system when the community has the responsibility of selecting the external members of the council (Okojie, 2005). At the faculty, department and units levels, the system also enjoys some level of administrative responsibilities and autonomy. The university system depends reliably on the committee system. Although the management sometimes usurps the powers of committees, it is only through the committees that some sensitive matters on appointments; promotion and discipline; and admissions are better addressed. Decisions in the system require consensus building, consultations and fair hearing. The hierarchical structure of administration ensures a fair measure of accountability and due process.

Financial Autonomy: The economic crises and the resulting financial squeeze of the 1980's led to reduced public funding support to education. The introduction of structural adjustment programmes justified further reduction in public subsidies to higher education in many countries (Varghese, 2001). This explains the observed progressive decline in tertiary education funding in Nigeria. The consequences are reflected in the environment of the system; poor infrastructural and physical facilities, large class sizes, poor quality teaching and research, social vices and poor quality graduates. In the public universities, lack of financial and administrative autonomy, coupled with government pressure for stricter budget control and high debt profile have been mainly responsible for the near intolerable situation in the system. However, the reforms/innovations instituted through the NUC is addressing the situation. But the system has to find other solutions to problems precipitated by inadequate funds. But what is the institutional capacity to initiate and sustain income-generating activities in the long run? The government has responded to the relatively reduced resource availability by changing resource allocation policies, reorganizing and merging, reducing overhead expenditure and shifting the burden to direct beneficiaries. Each of these measures further hurts the system. The challenge to the system is financial autonomy. Of the institutional reforms, cost sharing measures and income generating activities are more promising (Osuntokun, 2007). 
University Autonomy in a Liberalized System

The evolution of the University System in Nigeria followed the same course of history as in most developing countries. The first tertiary education systems were imposed by the colonial masters. But immediately after independence, Nigeria, like most of the newly independent nations, realized that the absence of human capital hindered the productive deployment of physical capital and consequently, development (Okojie, 2005). This explains the absolute monopoly enjoyed by the public universities in Nigeria until the mid-1990s. To demonstrate the national concern, and the level of urgency needed to address the issue of human capital, the Federal Government of Nigeria acquired the then regional universities at Nsukka, Zaria, Ile-Ife and Benin. Although, provisions were made in the 1979 constitution for the establishment of private universities, they were withdrawn by a military decree in 1984, because of the gross abuse. However, the Federal Government Act No. 9 of 1993 has restored the provisions for the establishment of private tertiary institutions. To a large extent, this has liberalized the provision of tertiary education delivery in Nigeria (Okojie, 2005).

\section{Public Universities and Autonomy}

Public Universities (Federal and State) still have a larger share in the liberalized system. Perhaps, it is still too soon to expect the private universities to make a significant impact. But the Federal Government policy of no expansion and no new Federal Universities points to an exciting prospect for private providers of tertiary education delivery. To demonstrate its resolve, the former and present democratic governments have not established a new public Federal university since 1999. Although, recurrent grant, for all Federal Universities and inter-university centres, increased while the total capital grant decreased. However, the ETF has continued to provide the capital grants over years. This is an indication of the seriousness in the no-expansion policy. The carrying capacity exercises undertaken by the NUC recently has demonstrated the further resolve of government to stem expansion, in the absence of adequate facilities, in the system. The establishment of the Open University in 2002 demonstrates the direction of the Federal Government with respect to tertiary education delivery. Distance-learning concept is being encouraged, (Okojie, 2005; NUC, 2009). In response to the financial crunch, public universities have resorted to improving internally generated revenue, through cost-sharing and resource mobilization efforts. This has perhaps encouraged the proliferation of subdegree, pre-degree programmes and the weak affiliations and linkages. It also bastardized the Master of Business Administration (MBA) and other professional higher degree programmes. While, institutional and academic autonomies have improved, government still has control of councils through the chairman and its external members. The appointments of the Chancellor and the Vice-Chancellor are still the responsibilities of government. Academic autonomy is still weak because of the uniform prescriptions imposed by the Benchmark minimum academic standards for programmes in Nigerian universities by the NUC. The issue of admission through JAMB still needs to be examined to give universities a greater role for enhanced academic autonomy.

\section{Private Universities and Autonomy}

According to Okojie (2005), "Private Universities in Nigeria do not yet have significant impact on the system”. Recent enrolment figures indicate that none of the 79 
operating private universities had up to ten thousand students. For the time being, university autonomy is the least of private universities' concerns; yet, the ownership pattern will determine the level of autonomy that these institutions will have when they attain maturity. Private university regulations, on the other hand, are written in the same broad words as public university laws. Despite the background of private universities, they are still subjected to the autonomy issue being discussed. Notwithstanding the fact that their major source of funding is through internally generated revenue that come mostly from tuition fees, government still has firm control over these universities in terms of determination of curricula, admissions and operational laws. Their minimum academic standards and admission policies are subjected to scrutiny by the NUC and JAMB accordingly. Private universities, therefore, are not excluded from the autonomy reform being clamoured for by Nigerian universities. Indeed, they most need autonomy to reduce government's control over the rules and regulations guiding their operations.

\section{Implications of University Autonomy on the Operations of the System}

Having said all these, the questions to ask again are: what are the objectives of university autonomy and what are the advantages and disadvantages of implementing the change in higher education? The implications are twofold. First, the idea of changing to autonomous university system means the government is no longer a 100 percent fund provider. Second, the universities have to rack their brains in order to gain part of the income for their proper operations and all the university staff will be changed from government officers to autonomous university employees. In the case of students, they would have no choice but to pay a much higher tuition. One advantage is that the autonomous universities will have the freedom to define what they teach and how they teach it; they will serve people more effectively because they are less burdened by government's bureaucratic regulations and red-tape. There is little doubt that the concept of autonomy today has not become widely accepted. The general argument is that the socalled "university autonomy" is a no more than an excuse from government's inefficiency and reduces the burden from its budget. One difficult issue concerning university autonomy particularly as it is conceived in Nigeria has remained how successful it will fare in the system if government goes ahead to implement it contrary to the wishes of the big unions namely Academic Staff Union of Universities (ASUU), Senior Staff Association of Nigerian Universities (SSANU), Non-Academic Staff Union of Educational and Associated Institutions (NASU) and National Association of Nigerian Students (NANS). For the majority believe the concept of university autonomy in Nigeria to mean government's total surrender of its legitimate right to provide education to its citizens.

\section{Theoretical Framework}

Organisational theory as a social concept has several dimensions that cut across a multiplicity of disciplines, that is science, sociology, psychology, anthropology (Nwachukwu, 1988; Hatch, 1997). Its sources of inspiration revolve around four key perspectives namely; classical scholars i.e. Adam Smith (1776), Karl Marx (1867), Henri Fayol (1919) etc. All wrote and contributed to what is now studied as organisational theory. The second inspiration has to do with modernist thinkers of the 1950s and these include; Herbert Simon, Talcott Parsons, Alfred Gouldner etc. The third inspiration comes 
from the symbolic interpretations of the 1980s and notable scholars here include, Alfred Schutz, Thomas Luckman, and Kenneth Burke, among others. The fourth and last inspiration comes from the post-modern scholars of the 1990s. Notable amongst them are Michael Foucault, Charles Jencks, Richard Rorty etc. (Hatch, 1997). These scholars have in one way or the other given their inspirational contributions on what the concept of organisation is all about. Every organization, be it formal or informal, requires some level of autonomy and freedom to run its affairs. Every organization has two common features: it comprises people and has a distinct purpose or goal to achieve. Organisations have definite structural arrangement that control the functions and behaviour of its members (Henry et al., 1981). Organizational process on the other hand refers to the comprehensive arrangement of the parts that constitutes the organization. In this vein, work and people are systematically organized to achieve results (Nwachukwu, 1988). Every organization having acquired all these elements requires some level of power and authority to operate. Authority according to Weber (1947) refers to 'the probability that certain specific commands from a given source will be obeyed by a given group of persons". There are many forms of authority spanned across traditional authority, charismatic authority, legal authority and formal authority. Formal authority is considered by Weber (1947) and Simon (1958) as institutionalized authority, or more precisely, the institutionalized right to impose positive or negative consequences on others' behaviour. Formal authority therefore, is legally established authority that determines how a formal organization established under given rules and regulations can be run. The concept of autonomy is situated within the framework of institutional authority for the purposes of this research. It is delegated autonomy, in which the state delegated power to its subsidiary organizations to manage their affairs within the bounds of the law. For example, it is frequently stated that authority is derived from property ownership. Thus, despite its rigidity in the application of rules and regulations, the researcher has fully adapted the organizational theory to this research issue as a theoretical framework because organizations have various institutions and groups that require some level of freedom to operate.

\section{Methodology}

This study relied particularly on primary and secondary data, and appropriate tools designed to facilitate the collection of the sort of data needed for this work. For this study, the tools selected include questionnaires and oral interviews (to generate primary data), and documentary evidence (to generate secondary data), particularly for the purpose of writing the chapter on literature review. Data analysis relied largely on statistical evaluation; the Chi-Square was used for data interpretation and analysis. These tools were selected to suit the varied spectrum of respondents, and each is designed to generate data from a particular category of respondents, and to give a clear picture of the magnitude of the problem being researched. Data was actually collected from primary sources through questionnaires (close-ended and open-ended questionnaires), oral interviews and documentary evidence mainly from the National Universities Commission (NUC), Federal Ministry of Education, Joint Admissions and Matriculation Board (JAMB) and other relevant regulatory bodies like the Nigerian Council of Legal Education, Institute of Chartered Accountants of Nigeria (ICAN), Dental and Medical Council of Nigeria, the House Committee on Education of the Federal House of Representatives, and nine Nigerian 
universities. Specifically, universities selected from the first and second generation universities, specialized and state/private universities were covered in the following order: Ahmadu Bello University, Zaria and Ibadan - as first generation universities.

University of Jos and Ilorin - as second generation universities.

Federal University of Agriculture, Makurdi and Ladoke Akintola University of Technology, Ogbomosho - as specialized Universities.

Benue State University, Makurdi and Enugu State University of Science and Technology - as state owned universities; and

The Igbinedion University, Okada - as one of the private oldest established university.

The reason for the choice of JAMB, NUC, ICAN, NCLE, among others, as sample population for this research is based on the fact that apart from being regulatory bodies, these are major stakeholders in university education in Nigeria, besides they play very key roles in university policy implementation and administration. A total number of 450 questionnaires were distributed among the nine Nigerian universities selected; out of these, a total number of 337 were retrieved, while 113 were lost. Out of the total of 450 questionnaires, 270 were administered on academic staff, while a total number of 180 were administered on administrative staff. Out of these, a total number of 194 questionnaires were retrieved from academic staff, while 143 were retrieved from administrative staff, bringing the total number of retrieved questionnaires to 337. From their experience, those with 30 years and above were particularly academic staff with the status of professor emeritus; while some have retired but have been re-engaged on contract basis. Most of the respondents were those with university degrees; those with Masters level degrees topping the list of the respondents.

For the oral interviews, letters seeking appointment for interviews were sent out to key public office holders of the institutions and regulatory bodies. Appointments for interviews were set and suitable times agreed with most of the interviewees, while with some it was special intervention from very influential figures and politicians that it was possible to hold an interview with. Having fixed dates and times for the interviews, the researcher then drew up an interview schedule detailing the itinerary. Most of the persons interviewed are outside the researcher's domicile, and for the interviews, the researcher did not employ research assistants. This is to avoid cost, but most importantly to avail the researcher the opportunity to meet with these administrators and policy makers to ask first hand questions and probe further areas that the researcher feels would generate very useful data.

\section{Empirical results and discussion}

One of the commonest crises in Universities nowadays is the struggle as to who becomes a principal officer, especially the Vice-chancellor. Every University Professor desires to be a Vice-chancellor anytime there is a vacancy. Even the appointment of other key University officers such as the Registrar, Bursar and Librarian seems highly politicized these days. For effective University Management to be sustained, respondents were of the view that the selection of key University officers should be democratized, so that University staff can be a part of the selection of who should be their leader.

Proposition 1: Poor funding of universities by way of poor grants and subventions coupled with inconsistent remittance of grants to universities over the years have remained 
the major problems affecting the effective management of government-owned universities in Nigeria

Table 1: How well is your University Funded?

\begin{tabular}{|lc|c|c|}
\hline & & FREQUENCY & $\mathbf{\%}$ \\
\hline & Well & 136 & 40.4 \\
\hline & Poor & 193 & 57.3 \\
\hline$\chi^{2} \quad(1 \mathrm{df}) \quad 9.88$ & Source: Field survey
\end{tabular}

In Table 1,193 respondents representing 57.3 percent said that Nigerian universities are poorly funded while 136 representing 40.4 percent were of the opinion that the universities are well funded. Testing the responses at an alpha level of 0.05 X2 (1df) = 9.88, respondents significantly affirmed that our universities are poorly funded. Information from interviews reaffirmed that not only does the poor funding place the management of universities at a miserable state; the system has been at receiving end of our national socio-economic and political instability. As a result, some of its problems are beyond solution through the system's internal mechanisms. Interview results also revealed that poor funding and its associated problems of inadequate facilities such as hostels, lecture theatres, laboratories, and ill equipped libraries are common problems facing our universities, be they federal, state, or privately owned. Poor funding according to respondents have pushed many of our universities into serious financial traps to the extent that some cannot maintain even the already existing structures. Respondents further decried that poor funding has restricted the capacity of the system to procure and maintain equipment as well as train academic staff. A cross-examination of the responses revealed that 136 respondents representing 40.4\% held a contrary view. According to them, Federal universities are well funded because they draw their grants from the Federal Government, while private universities especially those managed by either the Mission or philanthropic bourgeois Nigerians also enjoy better funding through exorbitant cost sharing approach.

Table 2: Sources of Funding

\begin{tabular}{|c|c|c|}
\hline & FREQUENCY & $\%$ \\
\hline Government subvention & 183 & 54.3 \\
\hline Tuition fees & 67 & 19.9 \\
\hline $\begin{array}{c}\text { Grants from the private sector and non-governmental } \\
\text { organisations }\end{array}$ & 22 & 6.5 \\
\hline Loans and Foreign aid & 06 & 1.8 \\
\hline All of the above sources of funding & 54 & 16.0 \\
\hline
\end{tabular}

$\begin{array}{lllll}\chi^{2} & \text { (4df) } & = & 297.1 & \text { Source: Field survey }\end{array}$

Table 2, above shows some of the sources of funding available to Nigerian universities. From the responses, government subvention appears to be the most popular source of funding, followed by tuition fees. The Chi-square test conducted at an alpha level of $0.05 \square 2$ (4df) = 297.1 also significantly proved that government subvention and tuition fees have remained the commonest sources of funding in Nigerian universities. Very few respondents were of the view that the private sector and non-governmental organisations, and foreign aid constitute the other sources of funding the universities. Further information from interviews revealed that in some countries of the west such as New Zealand where universities are well funded, there is usually a collaborative effort 
between the government and the private sector in funding universities. Moreover, universities are given the autonomy to invest in property, borrow money from the business sector and generate revenue from tuition fees. Respondents further revealed that in Nigeria, apart from the limited sources of funding available to our universities, competing needs on government subvention are too numerous to the extent that sometimes subvention to universities are not released for several quotas or delayed. The level of poverty and the nature of under-development tend to place very high demands on government at the expense of university education.

In Nigeria, private sector participation in the funding of universities is generally not encouraging unlike the case of New Zealand, Malaysia among others. Respondents also revealed that it is expensive for universities to borrow money from financial houses in Nigeria because of the high interest rates. In private universities, respondents revealed that the major source of funding is tuition fees. Government for political reasons has over the years been restricting the charging of tuition fees to ensure that every child of adult age who qualifies gets university education. This gesture however is counterproductive as universities are poorly funded and can hardly maintain and acquire facilities. Respondents pointed out other sources of funding available to Nigerian universities to include; endowments, compulsory local government counterpart funding by way of an act of parliament especially for state universities, research grants and so on. The summary of the foregoing is that university autonomy has remained a problematic for government since it requires adequate funding for efficient management.

Proposition 2: Government inability to determine areas of intervention and collaboration with its universities on matters of management have remained a major source of erosion of autonomy and academic freedom in the ivory towers.

Table 3: Under what circumstances should Government intervene in the Internal Affairs of Universities?

\begin{tabular}{|c|c|c|}
\hline & FREQUENCY & $\%$ \\
\hline Funding only & 280 & 83.1 \\
\hline Condition of service and staff discipline & 27 & 8.0 \\
\hline Appointment of Principal Officers & 13 & 3.9 \\
\hline $\begin{array}{c}\text { Determination of Academic Curricula and } \\
\text { admissions }\end{array}$ & 11 & 3.3 \\
\hline
\end{tabular}

$\chi^{2} \quad(3 \mathrm{df})=628.74 \quad$ Source: Field survey 2005

Table 3 demonstrates that at an alpha level $0.05 \square 2$ (3df) $=628.74$, the respondents significantly pointed out circumstances under which government should intervene in the internal affairs of universities. Majority (83.1\%) suggested that the intervention should come mostly in the area of funding. Other views though insignificant were that government may also from time to time; intervene on matters involving staff conditions of service, appointments and academic matters such as admissions and determination of curricula. Information from oral interview reveals that autonomy does not mean the total exclusion of government in the affairs of Universities particularly regarding funding. Ideally, autonomy even craves for better funding of Universities by Government for the enhancement of quality research, academic programmes and facilities. Further information also revealed that autonomy does not preclude Government intervention in areas of appointment, discipline of staff, provision of welfare and admissions in Universities. It is evident from interview responses that while funding of Universities is a social 
responsibility of Government for the training of its citizens, it is essential to note that "he who pays the piper needs to dictate the tune". This implies that there has to be a balance between control and university autonomy. This then means that the role of Government in the internal administration of Universities can only be reviewed and repositioned to make way for a harmonious autonomous working relationship between universities and the government and its agencies but to the extent that the Ivory Tower as a community with its unique tradition is not dragged into obeying civil service rules.

Proposition 3: The relevance of the university to its immediate environment depends largely on the level of funding and autonomy granted it by its proprietor.

Table 4: Concept and benefits of university autonomy

\begin{tabular}{|l|c|c|c|c|c|c|}
\hline \multicolumn{7}{|c|}{ F R E Q U E N C Y } \\
\hline YES & $\%$ & No & $\%$ & $\chi^{2}$ & Df & S \\
\hline 303 & 89.9 & 28 & 8.3 & 228.46 & 1 & S \\
\hline$\chi^{2}$ & (1df) & \multicolumn{7}{|c|}{228.46} & \multicolumn{7}{c|}{ Source: Field survey 2005}
\end{tabular}

Table 4 significantly shows that 303 respondents or 89.9 percent as against 28 or 8.3 percent appreciated and understood the gains and benefits of university autonomy in promoting the efficient and effective management of universities. These benefits respondents noted can only materialise if only government and proprietors of universities (public and private) are willing to allow universities the opportunity of running their respective administration in accordance with the laws, edicts, and ordinances establishing such universities. Information from interviews reveals that excessive government control and erosion of autonomy creates a negative situation where universities are no longer able to attract and retain their best graduates into careers in academics. This issue if not addressed by way of improving the system might result to succession crises when the older lecturers and even seasoned university administrators retire from active service. More worrisome is that the lack of adequate incentives has crept into the system forcing even committed lecturers to spend less time engaging students in the rigours of academic work which universities were known for in the seventies and eighties. The laws establishing universities are, therefore clear that where autonomy is allowed to take its proper course as enshrined in the laws, the benefits must definitely emerge to better the management of university system.

Table 5: Benefits of University autonomy continued (ranked responses)

\begin{tabular}{|c|c|c|c|c|c|c|c|}
\hline \multicolumn{9}{|c|}{ F R E Q U E N C Y } & YES & $\mathbf{\%}$ & $\mathbf{N o}$ & $\mathbf{\%}$ & $\chi^{2}$ & df & Sig. \\
\hline Promotes Academic Excellence & 279 & 82.6 & 41 & 12.2 & 177.02 & 1 & H.S \\
\hline Enhances Quality and Competition & 272 & 80.7 & 48 & 14.2 & 156.80 & 1 & S \\
\hline Make Universities self-sustaining & 269 & 79.3 & 50 & 14.8 & 150.34 & 1 & S \\
\hline Improves University funding and management & 263 & 78.0 & 58 & 17.2 & 130.92 & 1 & S \\
\hline $\begin{array}{c}\text { Encourages participation through the Committee } \\
\text { System }\end{array}$ & 252 & 74.8 & 68 & 20.2 & 105.80 & 1 & S \\
\hline
\end{tabular}

Source: Field survey 2005.

Table 5 shows some of the benefits that are a derivative from University autonomy. At an alpha level of $0.05 \square 2(1 \mathrm{df})=177.02$, 156.80, 150.34, 130.92, 105.80 respectively there was a statistical significant relationship between autonomy and the benefits it can 
have on the entire university system in Nigeria. These benefits are evidenced in the promotion of academic excellence, enhancement of quality and competition in universities, make universities self-sustaining, improves funding and management, and encourages participation through the Committee system. Further investigation through oral interviews also reaffirmed that the benefits of University autonomy on the effective management of Universities are vested in: promotion of academic excellence; enhancement of quality and competition; self-sustenance of universities; improving university management and funding; and encouraging participation through the committee system. From the foregoing responses of respondents, the benefits of University autonomy in promoting stability and effective University management are tantamount to the democratization process of University administration for the attainment of quality and excellence in the ivory tower.

\section{Conclusion and policy recommendations}

This study has highlighted university autonomy as a necessary value that underpins a university system. It is the firm position of this work that the liberal application of values of university autonomy can take Nigerian universities especially government owned to greater heights meant to attain academic excellence. The study concludes that the nature and character of governance inherent in our universities could to a large extent determine the nature of autonomy that would over time bring changes to our universities that are desirable in restoring the culture of academic excellence for effective training and retaining of capacity that is comparable with world standards. Therefore, the study makes the following recommendations:

First, grant more autonomy to Universities to manage their affairs with limited interference from government by repositioning powers of regulatory agencies such as the National Universities Commission (NUC), Joint Admissions Matriculation Board (JAMB), Council of Legal Education, as well as government ministries and parastatals, to conform to the autonomy of universities as contained in the laws establishing universities in Nigeria. Second, improve funding by encouraging private sector participation in addition to government grant, as well as allow universities to charge reasonable and affordable tuition fees. The federal and state governments should increase budgetary allocation to the education sub-sector.

Third, as much as possible, the internal administration of Universities should be left in the hands of the Governing Councils and Board of Trustees as it is the case with private Universities.

More so, the appointment of Governing Councils and Principal Officers should be largely carried out with reasonable consent of Universities. Government should desist from compelling Universities to rely on public service circulars for their day to day administration since the Universities even run a calendar distinct from that of the civil service. Furthermore, government should expedite the process of restoring autonomy to Universities, so that the university administration can motivate educators, teachers, staff and students by way of increasing their level of psychological satisfaction to enable them to perform well because poor working conditions as they presently exist in Universities are dissuading talented individuals from taking up University appointments, especially in the area of teaching while learning is no longer competitive amongst students. 
Again, to improve the quality of graduates, admissions should conform to approved requirements and set criteria by respective Senates while self-reliant courses be mounted by Universities to meet challenges of the 21st century while Universities should be granted autonomy and allowed unfettered hands to source funds through private sector partnership. Last, appointment of members of Governing Councils, and Board of Directors in the case of private universities should be based on merit and cognate experience so that members would be largely people who are well informed on matters of university administration. As much as possible, political affiliations should be de-emphasised in appointing members of university councils.

\section{References}

1. Adamolekun, L. (2000) Politics and Administration in Nigeria. 3rd edition. Ibadan, Spectrum Books Limited,

2. Altbach, P. C. (2002). Centres and peripheries in the academic profession: the special challenges of developing countries. In: The decline of the GURU: The academic profession in developing and middleincome countries. Altbach, P.C. (Ed)

3. ASUU (2002). The National Scholar. A Publication of Academic Staff Union of Universities, September, 2002 Edition.

4. Hatch, J. M. (1997). Organisation Theory. Modern, Symbolic and Post-modern Perspectives. Oxford University Press, New York.

5. Henry, L., Williams, J., \& Gibson, H. (1981). Management and Organization. West-Chicago, SouthWestern Publishing Co. (Fourth edition).

6. Ibidapo-Obe, A. (2005). A synthesis of African Law. Concept Publications, Lagos.

7. Jaba, Elisabeta and Roman, Mihai Daniel and Pagliacci, Mario and Serban, Dana and Balan, Christiana Brigitte and Asandului, Mircea, Statistical Evaluation of the Students' Perception of Creativity (January, 15 2009). International Conference on Education, Research and Innovation, ICERI 2008 Proceedings, Madrid, Spain, Available at SSRN: https://ssrn.com/abstract=1328296 or http://dx.doi.org/10.2139/ssrn.1328296

8. National Association of University Women-NAUW (1998). Factors militating against peace in the Nigerian Universities: A Case Study of Ahmadu Bello University, Zaria. University of Nigeria, Nsukka and 9. NUC (2005). Bulletin on List of Nigerian Universities, Names of Vice-chancellors and address.

10. Nwachukwu, C. C. (1988). Management Theory and Practice. African F.E.P. Publishers Limited.

11. Obafemi Awolowo University, Ile-Ife: 1987-1996. Submitted to IFUW, 8 rue de L'Ancien Port CH 1201, Geneva, Switzerland.

12. Obaji, C.N. (2005) An Address Delivered by the Honourable Minister of Education at the Seventh Joint Consultative Meeting of the Policy Committee on Admissions into Degree Awarding Institutions, held at Idris Abdulkadir Auditorium, National Universities Commission, Abuja on Tuesday 13th September, 2005.

13. Obasanjo, O. (2000). Address on the Inauguration of Governing Councils of Federal Universities, Abuja: May.

14. Ojo, J.D. (1990). Law and University Administration in Nigeria, Lagos; Malthouse Publishing Limited.

15. Okojie, J. A. (2005). University Autonomy: The Ivory Tower at Cross roads. Convocation Lecture delivered at the Federal University of Agriculture, Makurdi on 29th April

16. Saint, W., Hartnett, T. \& Strassner, E. (2003). Higher education in Nigeria: A status report. High Educational Policy, 16: 259-281. https://doi.org/10.1057/palgrave.hep.8300021

17. Salim, B.A. (2003). Provision of access at tertiary level of educational system in Nigeria: The Joint Admissions and Matriculation Board Experience. Paper delivered at the Annual Public Lecture of Romak Ventures held at the Nigerian Institute of International Affairs, Victoria Island, Lagos on Tuesday, 11th November. 
18. Sambo, A.S. (2002). Managing the Autonomy Dispensation: The New Power Centres. Paper presented at 4th National Training programme for Senior University managers, National Universities Commission, Abuja; 9th - 13th December.

19. Simon, H.A. (1958). Organizations. New York: John Wiley and Sons Inc.

20. Sorkaa, A.P. (2001). University Autonomy and Academic Freedom: Problems and Prospects. A paper presented at the 2001 National Conference of the Association of Nigerian University Professional Administrators (ANUPA), held at Central Auditorium (North Core), University of Agriculture, Makurdi; 21st - 23rd November.

21. Varghese N. V. (2001). The limits to diversification of sources of funding in higher education UNESCO IIEP Contribution No. 34.

22. Varrella, S. (2020). Number of university students in Nigeria as of 2017, by gender and course of study. Retrieved from https://www.statista.com/statistics/1130794/number-of-university-students-in-nigeria/ 23. Weber, M. (1947). The Theory of Social and Economic Organizations, New York, Free Press. Creative Commons Attribution - Non Commercial - No Derivatives 4.0 International License. 